\title{
Evolution of Androgenic Deprivation in Treatment of Prostate Cancer in Kinshasa
}

\author{
Dieudonné Molamba Moningo ${ }^{1,2,3 *}$, Junior Konga Liloku',3, Alpha Tsita Mafuta ${ }^{1,2}$, \\ Matthieu Nkumu Loposso1,2, Pablo Nkutima Diangienda ${ }^{1,2}$, \\ Augustin Mongalembe Punga Maole ${ }^{1,2}$, Richard Koseka Demongawi ${ }^{2,3}$, Nkodila Aliocha ${ }^{4}$
}

\author{
${ }^{1}$ Service of Urology, University Hospital of Kinshasa, Kinshasa, DRC \\ ${ }^{2}$ Department of Surgery, Faculty of Medicine, University of Kinshasa, Kinshasa, DRC \\ ${ }^{3}$ Clinic of Pointe-à-Pitre, Kinzanzi Quarter 11D, Kinshasa, DRC \\ ${ }^{4}$ Public Health School, Faculty of Medicine, University of Kinshasa, Kinshasa, DRC \\ Email: *dmoningo@yahoo.fr
}

How to cite this paper: Moningo, D.M., Liloku, J.K., Mafuta, A.T., Loposso, M.N., Diangienda, P.N., Maole, A.M.P., Demongawi, R.K. and Aliocha, N. (2021) Evolution of Androgenic Deprivation in Treatment of Prostate Cancer in Kinshasa. Open Journal of Urology, 11, 137-157. https://doi.org/10.4236/oju.2021.114014

Received: February 28, 2021

Accepted: April 25, 2021

Published: April 28, 2021

Copyright (c) 2021 by author(s) and Scientific Research Publishing Inc. This work is licensed under the Creative Commons Attribution International License (CC BY 4.0).

http://creativecommons.org/licenses/by/4.0/

\begin{abstract}
Context and Objective: Prostate cancer (PCa) is hormone-dependent cancer. In our area, most patients often arrive at the locally advanced stage or the metastatic stage. This justifies the choice of androgen deprivation as the mode of treatment. The objective of this study was to describe the socio-demographic characteristics of patients with PCa. Identifying the period during which the disease remains susceptible to androgen deprivation. Assessing the patient's prognosis in terms of survival. Methods: This is a retrospective observational study of the course of patients managed for PCa. It involved 51 cases and was conducted at the Pointe à Pitre clinic (CPAP) in Matete Township during a period of 4 years (from March 2014 to June 2018). Results: The mean age of patients was $69.4 \pm 9.7$ years (40 - 92 years); $39.2 \%$ of patients with PCa were aged between 70 - 79 years; $45.1 \%$ had consulted for dysuria and $25.5 \%$ were hypertensive. All had performed the prostate biopsy, $47.1 \%$ were diagnosed at the metastatic stage, with PSA $\geq 100 \mathrm{ng} / \mathrm{ml}$, Gleason scores 8 - 10, and clinical-stage TNM 3 - 4. About 51\% were subjected to androcure, $23.5 \%$ had been surgically cased and 3.9\% had undergone radical prostatectomy. $41.1 \%$ had resisted castration within a median of 1.4 years of response to treatment. The median survival was 30 months, with a mean survival of 26.6 months. Conclusion: Prostate cancer involved most of the patients in the age bracket of 70 to 79 years. The diagnosis was performed lately with a high resistance rate of castration and median survival of 30 months.
\end{abstract}

\section{Keywords}

Deprivation, Prostate Cancer (PCa), Pointe à Pitre Clinic (CPAP) 


\section{Introduction}

Prostate cancer ( $\mathrm{PCa}$ ) is the most common cancer in men in America (AfroAmericans and Afro-Caribbean) and Europe [1] [2] [3]. Patients with localized or sometimes locally advanced forms benefit from radical prostatectomy or radiotherapy. On the other hand, in patients with aggressive or metastasized forms; the treatment options may be radiotherapy but more commonly androgen deprivation [4]. To reduce the plasma level of testosterone and its derivative, dihydrotestosterone (DHT), androgen deprivation; apart from surgical castration still used by Anglo-Saxons, other practitioners prefer hormone therapy [5]. This hormone therapy has evolved with the emergence of LH-RH analogs, then treatment with non-steroidal anti-androgens, and finally, more recently, LH-RH antagonists, and Gn-RH agonists [6]. Depending on the patient's response, this hormone therapy goes from the first to the third line [7] [8]. Over $90 \%$ of patients treated respond to androgen deprivation. Unfortunately, transiently, its duration varies from a few months to a few years. The median being 12 to 18 months, then relapse is observed in $100 \%$ of cases. After the escape from this first line of hormone therapy, responses to alternative hormonal manipulations are rare, the tumor is resistant to castration [7] [8]. Once the hormone-independence stage has been reached, the tumor is resistant to castration. Median overall survival is 34 months [6]. Castration-resistant PC (CRPC) is an advanced form characterized by disease progression after surgical or pharmaceutical castration (androgen deprivation). The process by which prostate cancer cells become resistant to castration is not clear, but androgenic privations have been shown to offer a selective advantage to androgen-independent cells, which eventually grow and repopulate the tumor [9]. Compared with castration sensitive PCa, the prognosis of patients with CRPC is poor and survival is reduced. Until very recently, treatment options were mainly limited to symptomatic relief of bone metastases, which are more common in CRPC than in the castration-sensitive form [9] [10] [11] [12]. To provide a clear picture of the burden of CRPC, one must consider the prevalence of the disease, the relative time of onset versus diagnosis, patient characteristics including demographics, comorbidity, the onset of disease, metastatic form, and probable survival. There is, however, insufficiency of epidemiological evidence specifically characterizing CRPC outside of the settings of controlled trials in which patients may not represent the general population and normal disease progression. This can lead to its sub-optimal management; for example, the identification of patients with CRPC who are at risk of developing metastases is currently hampered by a poor understanding of its real epidemiology. Identifying people with CRPC may seem straightforward after androgen deprivation (drug or surgical). The characterization of the disease in epidemiological terms, eg incidence, prevalence, and survival, is however less clear. This can be attributed at least in part to the difficulty of defining, and therefore of studying, the patient population. The varying terminology-CRPC, HRPC (Hormone-refractory PCa), AIPC (Androgen-independent PCa), ERPC (Endocrine-resistant $\mathrm{PCa}$ )-reflects subtle differences in dentition that may hamper 
research comparison. Practitioners can also use a variety of diagnostic methods: prostate-specific antigen (PSA) assays, the development of metastases, or other factors to determine if a patient is defined as CRPC. The recently published European Association of Urology (EAU) guidelines aim to standardize the diagnosis of CRPC and include a list of five defining factors of CRPC [4].

These are as follows:

- Serum testosterone level.

- Three consecutive increases in Prostate Specific Antigen (PSA) 2 weeks apart resulting in two increases of $50 \%$ over the nadir.

- Anti-androgen stops for at least 4 weeks.

- Progression of PSA despite secondary hormonal manipulations.

- Progression of bone or soft tissue damage.

CRPC is a heterogeneous disease, and despite the availability of such guides for diagnosing CRPC, in practice, this can vary. Also, besides, the routes of treatment and clinical practice, particularly the stage of the disease at the onset of androgen deprivation therapy, vary widely between geographic locations and even the individual's clinic. Therefore, establishing common epidemiological estimates for the CRPC population becomes very complex and may become less relevant for individual scenarios [13].

In our environment, most affected patients consult at the advanced stage of the disease; thus, justifying androgen deprivation as a mode of treatment.

This study aimed to improve the clarity of the epidemiological evidence around CRPC, by identifying, assessing, and describing the most relevant elements that characterize the affected patient population using observational data.

Our objective was to assess the responses to hormonal deprivation, patient survival and to identify the different predictors of mortality.

\section{Methods}

Nature, Period, Framework and parameters of interest.

This is a retrospective observational epidemiological study that focused on the evolution of the 51 patients followed for PCa at the Pointe à Pitre Clinic during the period from March 2014 to June 2018. Pointe-à-Pitre Clinic is a non-profit organization, non-denominational and nonpolitical called "PROSTATE CANCER VIGILANCE AFRIQUE CENTRALE", PCVAC in acronym was created in Kinshasa, capital of the DRC on April 27, 2016. The head office of the association is in Kinshasa, within the Clinic cited above in the city of Kinshasa province in Matete Township, Kinzazi district, $\mathrm{n}^{\circ} 11 \mathrm{D}$ in Matete Health District. During the entire study period, 1364 patients were received at the CPAP and we identified 165 cases of prostate cancer (12\%) and among them, only 51 cases were retained to constitute our sample of coverage. Among the 165 patients, many were excluded because their follow-up was incomplete (PSA and Testerone). Our parameters of interest were age, profession, marital status, place of residence, complaints, cTNM, PSA, testosterone biopsy, prostate ultrasound, MRI results, Scintigraphy, radiography (pelvis and column), histological result, Gleason score, 
stage of progression, treatment, patient survival, a predictor of mortality. The androgen deprivation method has been either surgical (bilateral orchidectomy) or chemical (hormone therapy). We used for hormonotherapy, Cyproterone acetate (50 - $100 \mathrm{mg}$ ), Gosereline (10.8 mg) Bicalutamide (50 mg), and Docetaxel for the chemotherapy. Some patients who have undergone radical prostatectomy have received complete hormone therapy or orchidectomy for PCa recurrence.

\subsection{Inclusion Criteria}

We considered patients' files with a PCa which was treated and operated during the period of our study.

\subsection{Non Inclusion Criteria}

Incomplete or absent files on during data collecting have not been taken into account.

\subsection{Collection of Data}

We collected data by completing an ad hoc form related to the documentary review focused on the medical records and registers of patients.

\section{Statistical Analyses}

The data were computerized using Excel 2010 software and were analyzed using SPSS version 17 software. Tables or graphs were used, as appropriate, for the presentation of the results. The continuous quantitative variables with Gaussian distribution were presented as mean \pm standard deviation; those with non-normal distribution in the form of the median (extremes). Qualitative variables were described as relative frequency (\%). Comparison of proportions, medians, and means was performed using Chi-square, Mann Whitney Wilcoxon, and Student's t-tests, respectively. Independent determinants of resistance to surgical castration and PSA $\geq 100 \mathrm{ng} / \mathrm{ml}$ were identified using logistic regression. Kaplan Meier's method estimated the probability curve of resistance to surgical castration. It also described survival between the date of diagnosis of $\mathrm{CaP}$ and death (complete data) and the end of the study (censored data). The Log-rank test was used to compare survival curves. Cox's regression looked for independent predictors of mortality.

A p-value $<0.05$ was considered the threshold of statistical significance.

\section{Ethical Considerations}

During the collection and analysis of our data, confidentiality was strictly enforced.

\section{Results}

\subsection{General Characteristics of the Study Population}

About 51 patients, the average age was $69.4 \pm 9.7$ years, with extremes of 40 to 92 
years. The age range of 70 to 79 years was the most common (39.2\%). Obstructive signs and irritative signs were respectively $72.5 \%$ and $33.3 \%$. Dysuria was the obstructive symptom that most prompted patients to consult $(45.1 \%)$ followed by nycturia (23.5\%) like irritative symptoms. Hypertension was the most common comorbidity (25.5\%). It appears that; $47.1 \%$ of PCa were diagnosed at the metastasis stage, followed by cancers at high risk of progression (25.5\%). Only $7.8 \%$ of cancers were at low risk. The metastases were from localizations variables; bone (50\%), multiples (20\%), ganglion $(16.7 \%)$ and testicles $(12.5 \%)$. The year 2014 saw more consultations (37.2) and the highest mortality rate was observed during the year 2017 (50\%). The overall mortality rate was $19.6 \%$ and overall survival was $80.4 \%$ (Table 1 ).

Table 1. General characteristics of the population of the study.

\begin{tabular}{|c|c|c|c|c|}
\hline Variables & $\begin{array}{c}\text { PSA (ng/ml) } \\
\text { Average (extreme) }\end{array}$ & $\begin{array}{l}\text { Sample } \\
(\mathrm{n}=51)\end{array}$ & $\begin{array}{c}\text { Pourcentage } \\
\text { (\%) }\end{array}$ & $\begin{array}{l}\text { Death } \\
\text { n (\%) }\end{array}$ \\
\hline Age (year) & & $69.4 \pm 9.7$ & & \\
\hline Average & & $(40-92)$ & & \\
\hline$<60$ years & & 7 & 13.7 & - \\
\hline $60-69$ years & & 17 & 33.3 & - \\
\hline $70-79$ years & & 20 & 39.2 & - \\
\hline$\geq 80$ years & & 7 & 13.7 & - \\
\hline \multicolumn{5}{|l|}{ Symptoms } \\
\hline Obstructive signs & & 37 & 72.5 & - \\
\hline Irritative signs & & 17 & 33.3 & - \\
\hline Haematuria & & 4 & 7.8 & - \\
\hline \multicolumn{5}{|l|}{ Medical history } \\
\hline Arterial hypertension & & 13 & 25.5 & - \\
\hline Diabetes & & 6 & 11.8 & - \\
\hline PSA & $51,5(34.3-\geq 100,0)$ & 51 & 100 & - \\
\hline \multicolumn{5}{|l|}{ Stage of diagnosis } \\
\hline Metastatic cancer & & 24 & 47.1 & - \\
\hline High-risk cancer & & 13 & 25.5 & - \\
\hline Medium risk cancer & & 10 & 19.6 & - \\
\hline Low-risk cancer & & 4 & 7.8 & - \\
\hline Metastasis locations & & n (24) & 47.1 & - \\
\hline Bones & & 12 & 50.0 & - \\
\hline Nods & & 4 & 16.7 & - \\
\hline Testis & & 3 & 12.5 & - \\
\hline Multiples & & 5 & 20.8 & - \\
\hline Annual frequency and death & & & & $10(19.6)^{*}$ \\
\hline 2014 & & 19 & 37.2 & $1(5.2)$ \\
\hline 2015 & & 6 & 11.7 & $2(33.3)$ \\
\hline 2016 & & 14 & 27.4 & $1(7.1)$ \\
\hline 2017 & & 12 & 23.5 & $6(50)$ \\
\hline General survival in 4 years & & 41 & 80.4 & - \\
\hline
\end{tabular}

${ }^{*}$ Global mortality in 4 years. 


\subsection{Treatment and Evolution}

The treatment varied depending on the case (Hormone therapy, Surgery, chemotherapy):

- Ciproterone Acetate (Androcure) 50.9\%;

- The Goserelin-Bicalutamide combination in $45.0 \%$;

- Surgical castration in 23.5\%;

- Surgical castration was associated with TURP in $11.8 \%$ of cases;

- Radical prostatectomy in 3.9\%.

From an evolutionary point of view; the rate of castration resistance was $43.1 \%$ within a median of $1.4(1-3)$ years of response to treatment (Table 2 ).

\subsection{Evaluation of Castration Resistance}

Castration resistance was observed from the 5th month of treatment, especially for carrier patients with metastases.

\subsection{Resistance to Castration According to Gleason Score}

Patients with a Gleason score between 8 and 10 had a higher frequency of resistance compared to those with a Gleason score between 6 and 7; log-rank test ( $\mathrm{p}$ $=0.018$ ) (Figure 1).

\subsection{Risk of Resistance According to the D'AMICO Classification}

According to D'AMICO's classification, the risk of castration resistance was variable:

- Twice for the intermediate-risk PC [OR 2.02 95\% CI (1.45 - 3.90); $\mathrm{P}=0.021$ ];

- Three for high-risk PC [OR 2.95 95\% CI (1.36 - 4.69); P = 0.041];

- And 6 times for metastatic CaP [OR 5.88 95\% CI (1.62 - 7.99); P = 0.019] (Table 3).

Table 2. Distribution of patients according to treatment mode.

\begin{tabular}{ccc}
\hline Variables & $\begin{array}{c}\text { Sample } \\
(\mathbf{n}=\mathbf{5 1})\end{array}$ & $\begin{array}{c}\text { Pourcentage } \\
(\%)\end{array}$ \\
$\begin{array}{c}\text { Traitement } \\
\text { Hormonotherapy }\end{array}$ & 49 & 95.9 \\
Ciprotérone acetate & 26 & 50.9 \\
Goselerine/Bicalutamide & 23 & 45.0 \\
Goselrine/Bicalutamide Chemotherapy & 2 & 3.3 \\
Surgery & 28 & 54.9 \\
Surgical Castration & 12 & 23.5 \\
TURP alone & 8 & 15.7 \\
TURP + surgical castration & 6 & 11.8 \\
Radical Prostatectomy & 2 & 3.9 \\
Evolution & 22 & 43.1 \\
\hline
\end{tabular}


Table 3. Distribution of resistance according to the D'AMICO classification.

\begin{tabular}{cccccc}
\hline \multirow{2}{*}{ Classification of D'Amico } & \multicolumn{2}{c}{ Resistance to castration } & & \multirow{2}{*}{ OR (IC95\%) } \\
\cline { 2 - 3 } & No & Yes & & & \\
\hline Low risk cancer & $2(6.9)$ & $2(9.1)$ & & 0.818 & 1 \\
Intermediate risk cancer & $7(24.1)$ & $3(13.6)$ & & 0.021 & $2.02(1.45-3.90)$ \\
High risk cancer & $8(27.6)$ & $5(22.7)$ & & 0.041 & $2.95(1.36-4.69)$ \\
Metastatic cancer & $12(41.4)$ & $12(54.5)$ & 0.019 & $5.88(1.62-7.99)$ \\
\hline
\end{tabular}

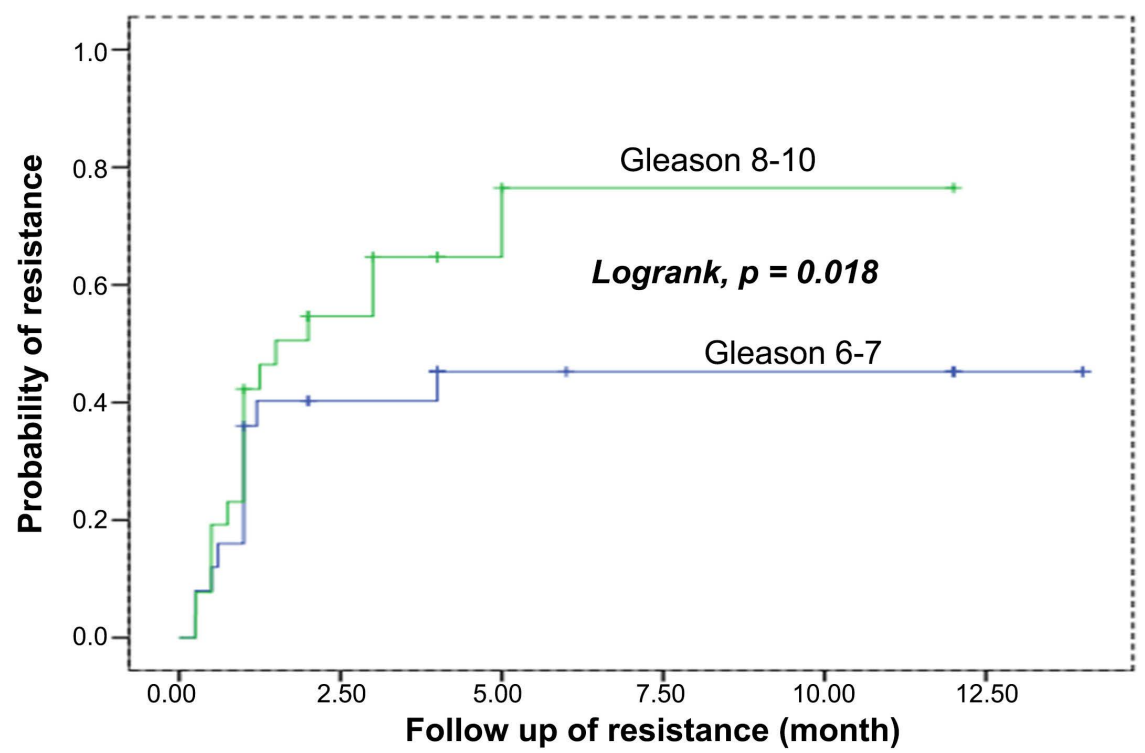

Figure 1. Gleason score and castration resistance.

\subsection{Resistance to Castration According to Clinical Signs}

Dysuria came first in $39.1 \%$, followed by pollakiuria in $30.4 \%$, nocturia in $26.1 \%$, and bone pain in $21.1 \%$ of cases (Table 4 ).

\subsection{Assessment of Prostate Specific Antigen Rate and Testosterone (ng/ml)}

During treatment, the PSA level tended to decrease for all patients. Its increase has been observed in some patients from the 4 th dosage. The mean PSA was 51.5 $(0.3$ - 2528.7) $\mathrm{ng} / \mathrm{ml}$ for un median of $7.75 \mathrm{ng} / \mathrm{ml}$. However, the testosterone level which reached the castration rate still tended to cancel out. Its average was 2.8 $\mathrm{ng} / \mathrm{ml}(0.5-8.15)$.

\subsection{Prostate Specifin Antigen Evaluation According to Age, cTNM, and Gleason Score}

The PSA level was not statistically significant ( $p$ 0.779) compared to the ages of the patients. The increase in PSA level was influenced by clinical stage cT3 - cT4 [OR $15.095 \%$ CI $(2.02-17.11) ; \mathrm{p}=0.006$ ], with a statistically significant difference in cT1 - cT2 (p 0.006) and score Gleason [OR 6.07 95\% CI (1.49 - 24.76)] without any statistically significant difference in score $6-7(\mathrm{p}=0.011)$ (Table 5). 
Table 4. Distribution of clinical signs in patients resistant to castration.

\begin{tabular}{ccc}
\hline Paramètres & $\begin{array}{c}\text { Sample } \\
(\mathbf{n}=\mathbf{2 3})\end{array}$ & $\begin{array}{c}\text { Pourcentage } \\
(\%)\end{array}$ \\
\hline Dysuria & 9 & 39.1 \\
Pollakiuria & 7 & 30.4 \\
Nycturia & 6 & 26.1 \\
Bone pain & 5 & 21.7 \\
Urinary incontinence & 4 & 17.4 \\
Mictalgia & 3 & 13.0 \\
Drop by drop urination & 3 & 13.0 \\
LLE & 2 & 8.7 \\
\hline
\end{tabular}

Table 5. Distribution of Prostate Specific Antigen levels by age, cTNM, and Gleason score.

\begin{tabular}{|c|c|c|c|c|c|}
\hline \multirow{2}{*}{ Variables } & \multicolumn{3}{|c|}{ PSA (ng/ml) } & \multirow{2}{*}{$\mathrm{p}$} & \multirow{2}{*}{ OR (IC95\%) } \\
\hline & All & $<100$ & $\geq 100$ & & \\
\hline Age & & & & 0.779 & \\
\hline$<60$ years & $7(13.7)$ & $3(11.5)$ & $4(16.0)$ & & 1 \\
\hline $60-69$ years & $17(33.3)$ & $8(30.8)$ & $9(36.0)$ & & $0.86(0.13-5.82)$ \\
\hline $70-79$ years & $20(39.2)$ & $13(50.0)$ & $7(28.0)$ & & $0.54(0.09-3.41)$ \\
\hline$\geq 80$ years & $7(13.7)$ & $2(7.7)$ & $5(20.0)$ & & $1.50(0.14-16.54)$ \\
\hline cTNM & & & & 0.006 & \\
\hline $\mathrm{cT} 1-\mathrm{cT} 2$ & $14(76.9)$ & $7(53.8)$ & $7(58.3)$ & & 1 \\
\hline cT3 - cT4 & $11(23.1)$ & $6(46.2)$ & $9(41.7)$ & & $15.0(2.02-17.11)$ \\
\hline Gleason & & & & 0.011 & \\
\hline $6-7$ & $25(49.0)$ & $13(50.0)$ & $12(48.8)$ & & 1 \\
\hline $8-10$ & $26(51.0)$ & $13(50.0)$ & $13(52.2)$ & & $6.07(1.49-24.76)$ \\
\hline
\end{tabular}

\subsection{Assessment of Patients' Survival}

The probability of patient survival was $92.2 \%$ at 10 months, $84.3 \%$ at 15 months, $82.4 \%$ at 20 months, and $80.4 \%$ at 48 months, respectively. The median patient survival was 30 (24 - 30) months and the mean survival was 26.6 months.

\subsection{Assessment of Patients' Survival versus Castration Resistance}

Patients resistant to castration had significantly reduced survival compared to those who did not $(\mathrm{p}=0.029)$ (Figure 2).

\subsection{Assessment of Survival about Prostate Specific Antigen Level}

The survival of patients with a PSA level $\geq$ of $100 \mathrm{ng} / \mathrm{ml}(\mathrm{p}=0.006)$ was significantly lower compared to the others (Figure 3). 


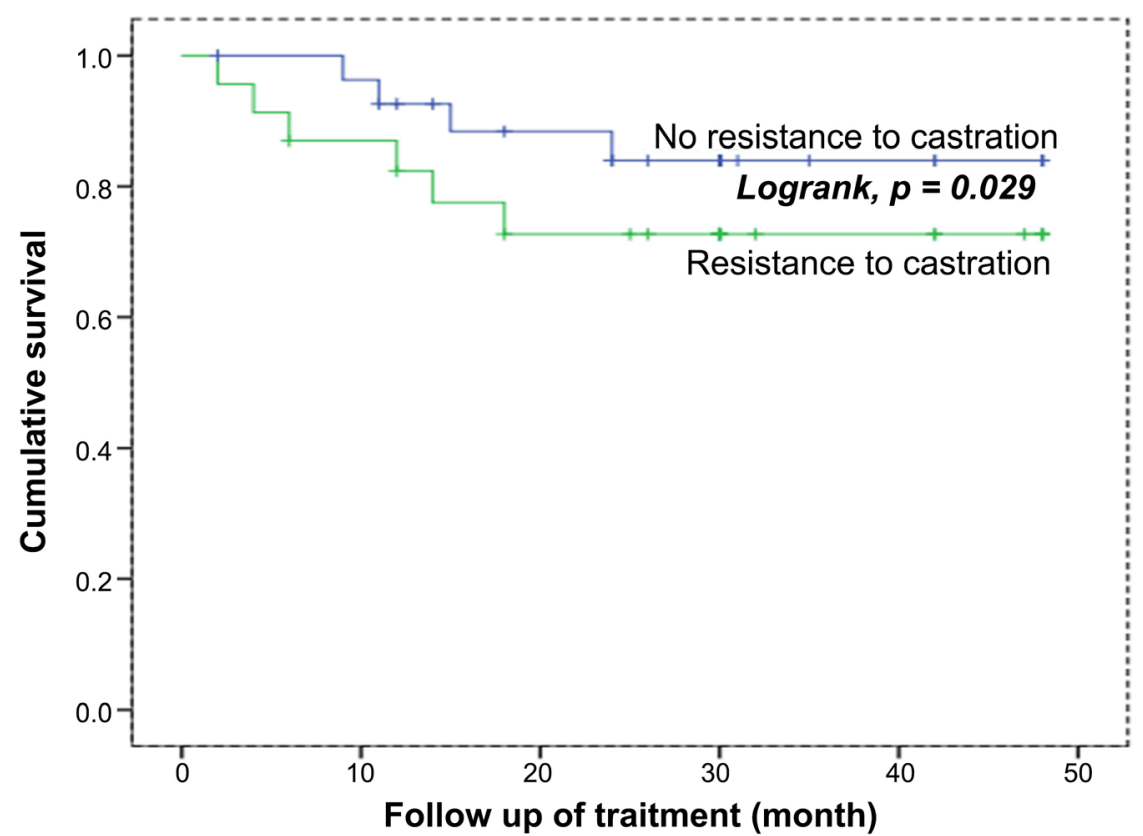

Figure 2. Patients' survival versus castration resistance.

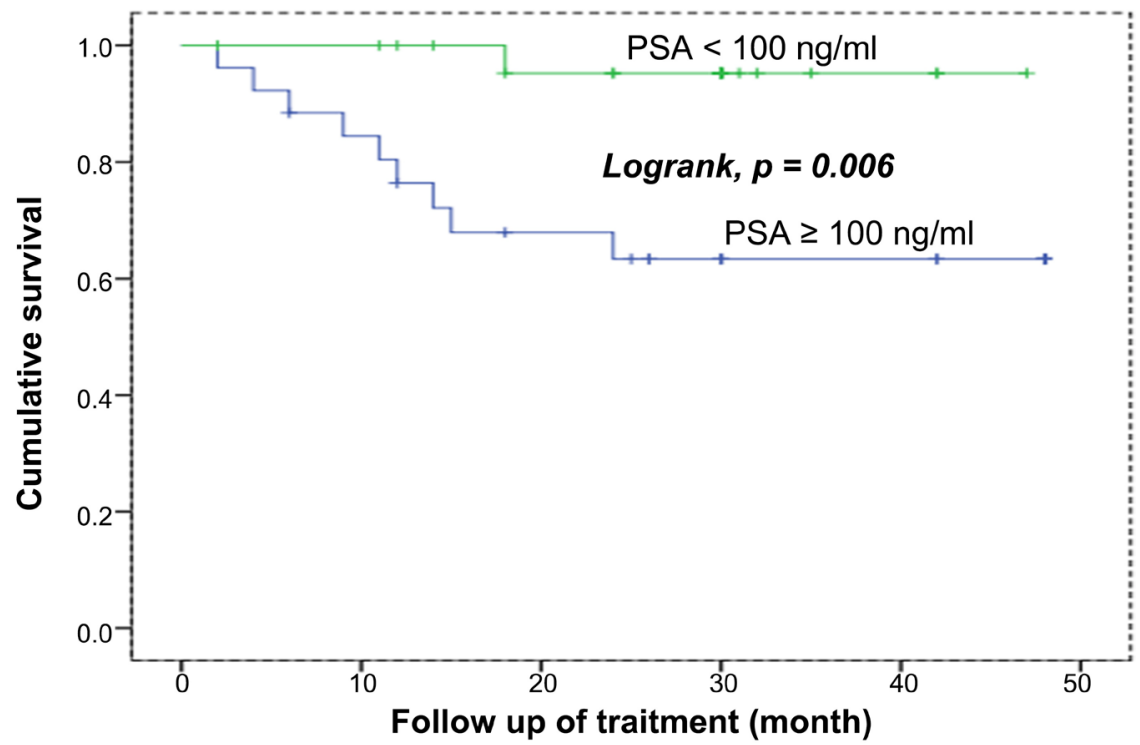

Figure 3. Survival curve as a function of the prostate specific antigen level.

\subsection{Assessment of Survival about Gleason Score}

The survival of patients with a Gleason score of 8 - 10 (p 0.004) was significantly lower than those with a score of 6 - 7 (Figure 4).

\subsection{Predictors of Mortality}

In univariate analysis; PSA levels $\geq 100 \mathrm{ng} / \mathrm{ml}$ [HR 10.20 95\% CI (1.29 - 13.56); $\mathrm{p}$ $=0.001]$, Gleason score $8-10$ [HR $10.9798 \%$ CI $(1.39-16.68) ; \mathrm{p}=0.035] \mathrm{ca}-$ stration resistance [HR $3.9895 \% \mathrm{CI}(1.56-7.04) ; \mathrm{p}=0.017$ ] and metastases [HR $2.6795 \%$ CI $(1.69-10.35), p=0.007]$ were predictors of mortality, without any 


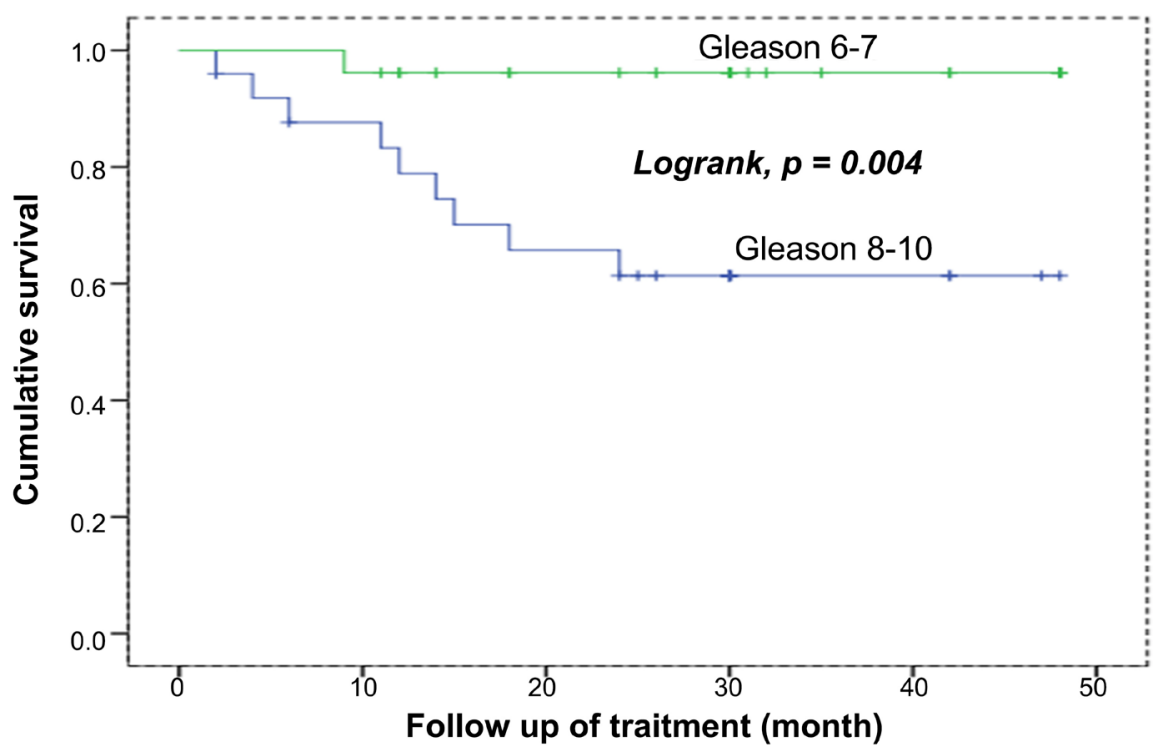

Figure 4. Survival about Gleason score.

significant difference within each group (Table 6). In multivariate analysis, the Gleason score 8 - 10 [HRa 10.15 95\% CI $(2.18$ - 12.23); $\mathrm{p}=0.035$ ] and the PSA $\geq$ 100 [HRa $8.4995 \%$ CI $(2.15-10.56) ; \mathrm{p}=0.001$ ] were more evident as predictors of mortality (Table 6).

\section{Discussion}

The current study is one of the few to have explored the course of androgen deprivation in 51 patients treated for PCa Apart from the response to this hormonal deprivation, the objective was to evaluate the survival of the patients and to look for the different predictors of mortality. In Table 1, it was from the fourth decade that PCa was diagnosed in our patients with an average age of 69.4 years (40 - 92 years). Many studies report either an average around the sixth decade [3] [14] [15] [16] [17] or around the seventh decade [18]-[24] with extremes that do not show significant differences. Only one reports an average of 59.13 years [25] (Table 7).

Hypertension was the most common comorbidity in $25.5 \%$ of cases. Studies have explored the association of PCa with hypertension as comorbidity and report different results. Some report hypertension as the only comorbidity; $33.3 \%$ [17] and 35.4\% [26] cases. Others show an increased risk of PC [27], death [28], and an increased prevalence of PCa in hypertensive Africans [29]. Most of the patients were carriers of PCa diagnosed at the stage of metastasis followed by cases at high risk of progression and intermediate risk. Those of low risk have been rare. The same results are described in the literature, with the predominance of metastatic cancers for some authors [15] [21] [24] [29] [30]. Others report more on low-risk and intermediate-risk cancers [31] [32] [33]. Indifferent types of studies. Bone metastases predominated, followed by multiple locations and lymph nodes. PCa is first recognized as osteophytes cancer before any other 
Table 6. Distribution of patients according to the predictors of mortality.

\begin{tabular}{|c|c|c|c|c|}
\hline \multirow{2}{*}{ Variables } & \multicolumn{2}{|c|}{ Univaried Analysis } & \multicolumn{2}{|c|}{ Multivaried Analysis } \\
\hline & $\mathrm{p}$ & HR (IC95\%) & $\mathrm{p}$ & $\mathrm{HRa}$ (IC95\%) \\
\hline \multicolumn{5}{|l|}{ PSA (ng/ml) } \\
\hline$<100$ & & 1 & & 1 \\
\hline$\geq 100$ & 0.028 & $10.20(1.29-13.56)$ & 0.001 & $8.49(2.15-10.56)$ \\
\hline \multicolumn{5}{|l|}{ Gleason } \\
\hline $6-7$ & & 1 & & 1 \\
\hline $8-10$ & 0.023 & $10.97(1.39-16.68)$ & 0.035 & $10.15(2.18-12.23)$ \\
\hline \multicolumn{5}{|c|}{ Metastatic cancer } \\
\hline No & & 1 & & 1 \\
\hline Yes & 0.015 & $2.67(1.69-10.35)$ & 0.007 & $4.77(1.89-6.32)$ \\
\hline \multicolumn{5}{|c|}{ Castration resistance } \\
\hline Yes & & 1 & & 1 \\
\hline No & 0.029 & $3.98(1.56-7.04)$ & 0.017 & $3.15(1.25-5.36)$ \\
\hline \multicolumn{5}{|l|}{ cTNM } \\
\hline cT1 - 2 & & 1 & & 1 \\
\hline cT3 - 4 & 0.035 & $2.16(1.44-6.74)$ & 0.736 & $1.35(0.24-7.71)$ \\
\hline
\end{tabular}

Table 7. Char of mean age according to authors.

\begin{tabular}{cccc}
\hline Authors & Country & Mean Age & Year \\
\hline Carl K. et al. [14] & Colombia & $66.0(49-70)$ & 2007 \\
Laurent Brureau et al. [3] & Antilles & $68.0(46-95)$ & 2009 \\
Laurent Brureau et al. [15] & Guadeloupe & $66.4(46-95)$ & 2016 \\
B. Sine et al. [16] & Sénégal & $68.5(53-82)$ & 2016 \\
Dieudonné Moningo et al. [17] & DRC & $68.9(43-88)$ & 2018 \\
Hwang et al. [18] & USA & $73.0-$ & 2004 \\
Smith MR et al. [19] & NR & $75.0(60-80)$ & 2005 \\
Henry Botto et al. [20] & France & $70.6 \pm 8.8$ and 72.2 & 2007 \\
Daniel et al. [21] & USA & $70.0(67-81)$ & 2016 \\
Mohamed Ait Chtouk [22] & Morocco & $75.0(51-99)$ & 2016 \\
Rozet et al. [23] & France & $70.0-$ & 2016 \\
Maha Hussain et al. [24] & UK & $74.0(50-95)$ & 2018 \\
Ngandu TJ et al. [25] & Mbujimayi (DRC) & $59.1(57-60)$ & 2015 \\
Our study & DRC & $69.4(40-90)($ Table 1) & 2020 \\
\hline
\end{tabular}

NR: No reported.

localization [21] [34] [35] [36] [37] [38]. We used clinical signs, PSA and testosterone level, cTNM stage, Gleason score, and medical imaging to assess castration resistance in our patients. Everything was summed up in D'Amico's classification. Numerous studies have explored similar parameters in various ways to assess castration resistance in PCa [39] [40] [41]. Most patients had benefited from castration (hormonal or surgical), radical prostatectomy was very rare (3.9\%) (Table 2). These results are almost like those found in the literature [20] 
[42] [43] [44]. The castration-resistant cancer rate (CRPC) was $43.1 \%$ within a median of 1.4 ( 1 - 3 years) year (17 months) of response to treatment (Figure 1 ). Our results are different from those of other authors [11] [34] [45] [46] [47] [48]. Other studies [49] report that $10 \%$ to $20 \%$ of PCa evolve into CRPC approximately 5 years after the start of treatment (Table 8 ).

Gleason score 8 - 10 (log-rank; p = 0.018) (Figure 1), High-risk Cap [OR 2.95 95\% CI (1.36 - 4.69)] (Table 3), metastatic [OR 5.88 95\% CI (1.62 - 7.99)] (Table 3 ), and dysuria (Table 4) were providers of CPRC. These same results are reported by many researchers [11] [21] [34] [44] [49] [50] [51] [52]. The increase in PSA level was influenced by clinical stage cT3 - cT4 [OR 15.0 95\% CI (2.02 17.11); $\mathrm{p}=0.001$ ], and Gleason score 8 - 10 [OR 6.07 95\% CI $(1.49$ - 24.76); $\mathrm{p}=$ 0.035] (Table 5). These same results are repeated in many studies [53]-[58]. In terms of percentage, patient survival was $94.7 \%, 88.0 \%, 89.7 \%$, and $80.4 \%$ at 1 year, 2 years, 3 years, and 4 years, respectively. Three groups of auteurs report report different survival percentages. The first indicates a survival at 1 year, 2 years, 3 years, and 4 years between $80 \%$ to $90 \%$ [16] [21], the second suggests a 5 -year survival of $30 \%$ for CRPCs [55]. In the end, the Henry Botto team evokes a survival of $21.1 \% \%$ at 8 years [20].

In terms of months or years, the median patient survival was 30 [24]-[30] months and the mean survival was 26.6 months. Most studies already published report a median survival that varies between 14 to months, with certain differences depending on the stage, grade, and comorbidity [16] [18] [19] [20] [24] [34] [53] [59] [60]. Patients resistant to castration (LogRank, p = 0.029) (Figure 2 ), those with a PSA level $\geq 100 \mathrm{ng} / \mathrm{ml}$ (LogRank, p 0.006) (Figure 3) or a Gleason score 8 - 10 (LogRank, p 0.004) (Figure 4) had significantly reduced survival compared to the others. Other researchers come to the same conclusion [11] [21] [38] [61]. Searching for predictors of mortality; in univariate analysis; PSA levels $\geq 100 \mathrm{ng} / \mathrm{ml}$ [HR 10.20 95\% CI (1.29 - 13.56); $\mathrm{p}=0.001$ ], Gleason score 8 10 [HR $10.9798 \%$ CI (1.39 - 16.68); 0.035] resistance to castration [HR $3.9895 \%$ CI (1.56 - 7.04); $\mathrm{p}=0.017$ ] and metastases [HR 2.67 95\% CI (1.69 - 10.35); $\mathrm{p}=$ 0.007] were predictors of mortality, without any significant difference within each group. In multivariate analysis, the Gleason score 8 - 10 [HRa $10.1595 \%$ CI (2.18 - 12.23); $\mathrm{p}=0.035$ ] and the PSA level $\geq 100$ [HRa 8.49 95\% CI $(2.15$ 10.56) $\mathrm{p}=0.001$ ] (Table 6), were more prominent as predictors of mortality.

Table 8. Chart of castration resistance according to the authors (34).

\begin{tabular}{|c|c|c|c|c|c|}
\hline $\begin{array}{l}\text { Reference } \\
\text { (Autor) }\end{array}$ & $\begin{array}{l}\text { Type } \\
\text { (Study) }\end{array}$ & $\begin{array}{l}\text { Country } \\
\text { (Year) }\end{array}$ & $\begin{array}{c}\text { Age } \\
\text { (Patients) }\end{array}$ & $\begin{array}{l}\text { Period } \\
\text { (Study) }\end{array}$ & $\begin{array}{l}\text { Prevalence } \\
\text { (CRPC) }\end{array}$ \\
\hline Alemayehu [45] & Retrospective & USA (2001-2007) & $\geq 40$ ans & $>6$ years & $17.8 \%$ \\
\hline Morgan [46] & Retrospective & UK (1998-2008) & $\geq 40$ ans & $>10$ years & $11.2 \%$ \\
\hline Berruti [47] & Prospective & Italy (1996-2003) & $47-87$ years & 55 months & $53 \%$ \\
\hline Bianco [49] & Retrospective & USA (1990-1999) & - & $\begin{array}{c}1-145 \text { months } \\
\text { (Médiane } 55 \text { months) }\end{array}$ & $19 \%$ \\
\hline Our study & Retrospective & DRC (2014-2016) & $40-92$ years & 4 years & $43.1 \%$ \\
\hline
\end{tabular}


The same observation is made by many authors namely; the mortality is all the higher for high-grade, metastatic PCa, RCPC and a very high PSA rate [21] [36] [51] [61] [62] [63].

\section{Conclusion}

Prostate cancer is a public health challenge in our area. The average age of the patients was 69.4 years (40 - 92 years). Dysuria was the main symptom of medical consultation. Hypertension was the main comorbidity among our patients. Most of our patients have been diagnosed at metastasis stage or a high-risk stage of progression. Castration resistance was observed from the 5th month of treatment, especially for patients with metastases. The median patient survival was 30 months and the average survival was 26.6 months with a difference depending on the stage, grade, and comorbidity. The overall mortality rate was $19.6 \%$. The patients with castration resistance had significantly reduced survival.

\section{Limitations of the Study}

This publication is considered as a pilot study which will be validated by others. The interpretation of the results should consider the limitations. The lack of randomization of the subjects studied and the limited to one center introduced a selection bias and does not allow the generalization of our results. The retrospective nature of our cohort constitutes a significant loss of some useful information. The low socio-economic level of the patients made it impossible to carry out several paraclinical examinations which have a definite influence on the survival of patients. Finally, the relatively small size of the sample could not give enough power to statistical tests to detect possible associations between the variables of interest. To get around these methodological pitfalls, a multicenter randomized longitudinal cohort study is expected.

\section{Authors' Contribution}

Dieudonné Molamba Moningo: Research design and supervision.

Junior Konga Liloku: Data collection and writing.

Richard Koseka Demongawi: French English translator.

Nkodila Aliocha: Statistical analysis.

Other authors: Corrections, remarks, and suggestions.

\section{Conflicts of Interest}

The authors declare no conflicts of interest regarding the publication of this paper.

\section{References}

[1] Jema, A., Bray, F., Center, M., Ferlay, J., Ward, E. and Forman, D. (2011) Cancer Statistics, 2010. CA: A Cancer Journal for Clinicians, 61, 69-90.

https://doi.org/10.3322/caac.20107 
[2] Ferlay, J., Parkin, D.M. and Steliarova-Faucher, E. (2010) Estimates of the Cancer Incidence and Mortality in Europe at 2008. European Journal of Cancer, 46, 765-781. https://doi.org/10.1016/j.ejca.2009.12.014

[3] Brureau, L., Multigner, L., Wallois, A., Verhoest, G., Ndong, J.R., Fofana, M. and Blanchet, P. (2009) Cancer de la prostate en Guadeloupe: Incidence, mortalité, caractéristiques cliniques et anatomopathologiques. Bulletin du Cancer, 96, 165-170. https://doi.org/10.1684/bdc.2008.0811

[4] Heidenreich, A., Aus, G., Bolla, M., Joniau, S., et al. (2008) European Association of Urology Guidelines on Prostate Cancer. European Urology, 53, 68-80. https://doi.org/10.1016/j.eururo.2007.09.002

[5] Monika, J. (2007) Etude de l'Impact de mutations du domaine de liaison à l'ADN sur les fonctions du récepteur des androgènes dans le cancer de la prostate. Thèse de Doctorat en Science du vivant, Université Louis Pasteur Starsbourg, 258, 18-23.

[6] Ruffion, A., Pointaine, E. and Staerman, F. (2003) Traitement hormonal du cancer de la prostate métastatique. Progrès en Urologie, 13, 334-341.

[7] Culling, Z. (2013) Rôle of the androgen receptor axis in prostat cancer. Urology, 62, 21-26. https://doi.org/10.1016/S0090-4295(03)00698-8

[8] Felderman, B. and Felderman, D. (2001) The Development of Androgen-Independent Prostate Cancer. Nature Reviews Cancer, 1, 34-35. https://doi.org/10.1038/35094009

[9] Albertsen, P.C., Hanley, J.A., Gleason, D.F. and Barry, M.J. (1998) Competing Risk Analysis of Men Aged 55 to 74 Years at Diagnosis Managed Conservatively for Clinically Localized Prostate Cancer. JAMA, 280, 975-980. https://doi.org/10.1001/jama.280.11.975

[10] NICE (2008) National Institute for Health and Clinical Excellence Guidelines: Prostate Cancer: Diagnosis and Treatment. National Collaborating Centre for Cancer, London.

[11] Crawford, E.D. and Petrylak, D. (2010) Castration-Resistant Prostate Cancer: Descriptive yet Pejorative? Journal of Clinical Oncology, 28, 408. https://doi.org/10.1200/JCO.2010.28.7664

[12] European Association of Urology (2009) Guidelines on Prostate Cancer. https://uroweb.org/wp-content/uploads/05-Prostate-Cancer.pdf

[13] Kirby, M., Hirst, C. and Crawford, E.D. (2011) Characterising the Castration-Resistant Prostate Cancer Population: A Systematic Review. International Journal of Clinical Practice, 65, 1180-1192. https://doi.org/10.1111/j.1742-1241.2011.02799.x

[14] Gjertson, C.K., et al. (2007) Local Control and Long-Term Disease-Free Survival for Stage D1 (T2-T4N1-N2M0) Prostate Cancer after Radical Prostatectomy in the PSA Era. Urology, 70, 723-727. https://doi.org/10.1016/j.urology.2007.05.014

[15] Brureau, L., Moningo, D., Emeville, E., Ferdinand, S., Punga, A., Lufuma, S., Blanchet, P., Romana, M. and Multigner, L. (2016) Polymorphisms of Estrogen Metabolism Related Genes and Prostate Cancer Risk in Two Populations of African Ancestry. PLoS ONE, 11, e0153609. https://doi.org/10.1371/journal.pone.0153609

[16] Sine, B., Bagayogo, N.A., Thiam, A., Sarr, A., Zakou, A.R., Faye, S.T., Fall, B., Sow, Y., Diao, B., Fall, P.A., Ndoye, A.K. and Ba, M. (2016) Cancers de la prostate de score de Gleason supérieur ou égal à 8: Evaluation de la survie des patients. African Journal of Urology, 22, 243-248. https://doi.org/10.1016/j.afju.2016.01.011

[17] Moningo, D., Blanchet, P. and Maole, A.P. (2018) Profil Epidémiologique et Déterminants Génétiques du cancer de la prostate à Kinshasa. Ediditions universitaires européennes. 91-113. 
[18] Hwang, S.S., Chang, V.T., Alejandro, Y., Mulaparthi, S., et al. (2004) Study of Hormone Refractory Prostate Cancer: Hospital Care and Palliative Care Resource Use at a VA. Cancer Investigation, 22, 849-857. https://doi.org/10.1081/CNV-200039643

[19] Smith, M.R., Kabbinavar, F., Saad, F., Hussain, A., et al. (2005) Natural History of Rising Serum Prostate-Specific Antigen in Men with Castrate Nonmetastatic Prostate Cancer. Journal of Clinical Oncology, 23, 2918-2925. https://doi.org/10.1200/JCO.2005.01.529

[20] Botto, H., Rouprét, M., Mathieu, F. and Richard, F. (2007) Etude randomisée multicentrique comparant la castration médicale par triptoréline à la castration chirurgicale dans le traitement du cancer de la prostate localement avancé ou métastatique. Progrès en Urologie, 17, 235-239. https://doi.org/10.1016/S1166-7087(07)92270-8

[21] Moreira, D.M., Howard, L.E., Sourbeer, K.N., Amarasekara, H.S., Chow, L.C., Cockrell, D.C., Hanyok, B.T., Aronson, W.J., Kane, C.J., Terris, M.K., Amling, C.L., Cooperberg, M.R., Liede, A. and Freedland, S.J. (2016) Predictors of Time to Metastasis in Castration-Resistant Prostate Cancer. Urology, 96, 171-176. https://doi.org/10.1016/j.urology.2016.06.011

[22] Chtouk, M.A. (2016) Prise en charge du cancer de la prostate localement avancé et métastatique. Thèse du Doctorat en médecins, Université CADI AYYAD, Faculté de médecine et de Pharmacie, Marrakech, 11.

[23] Rozet, F., Hennequin, C., Beauval, J.B., Beuzeboc, P., Cormier, L., Fromont, G., et al. (2016) CCAFU recommandations nationales sur le cancer de la prostate 2016-2018. Progrès en Urologie, 27, S95-S143. https://doi.org/10.1016/S1166-7087(16)30705-9

[24] Hussain, M., Fizazi, K., Saad, F., Rathenborg, P., Shore, N., Ferreira, U., Ivashchenko, P., Demirhan, E., Modelska, K., De Phung, B.S., Krivoshik, A. and Sternberg, C.N. (2018) Enzalutamide in Men with Nonmetastatic, Castration-Resistant Prostate Cancer. The New England Journal of Medicine, 378, 26. https://doi.org/10.1056/NEJMoa1800536

[25] Ngandu, T.J., Kabongo, J.-M., Punga, M.A., Lebwaze, M.B., Moningo, D., Munabe, K.K.P. and Roux, J.J. (2015) Valeur du PSA dans le diagnostic du cancer de la prostate à Mbujimayi. Revue Médicale des Grands Lacs, 6, No. 4.

[26] Di Francesco, S., Robuffo, I., Caruso, M., Giambuzzi, G., Ferri, D., Militello, A. and Toniato, E. (2019) Metabolic Alterations, Aggressive Hormone-Naïve Prostate Cancer and Cardiovascular Disease: A Complex Relationship. Medicina (Kaunas), 55, 62. https://doi.org/10.3390/medicina55030062

[27] Hsing, A.W., Sakoda, L.C. and Chua, S. (2007) Obesity, Metabolic Syndrome, and Prostate Cancer. The American Journal of Clinical Nutrition, 86, 843-857. https://doi.org/10.1093/ajcn/86.3.843S

[28] Tilg, H. and Moschen, A.R. (2008) Role of Adiponectin and PBEF/Visfatin as Regulators of Inflammation: Involvement in Obesity-Associated Diseases. Clinical Science, 114, 275-288. https://doi.org/10.1042/CS20070196

[29] Häggström, C., Stocks, T., Ulmert, D., Bjørge, T., Ulmer, H., Hallmans, G., Manjer, J., Engeland, A., Nagel, G., Almqvist, M., Selmer, R., Concin, H., Tretli, S., Jonsson, H. and Stattin, P. (2012) Prospective Study on Metabolic Factors and Risk of Prostate Cancer. Cancer, 118, 199-206. https://doi.org/10.1002/cncr.27677

[30] Gueye, S.M., Zeigler-Johnson, C.M., Friebel, T., et al. (2003) Clinical Characteristics of Prostate Cancer in African Americans, American Whites, and Senegalese Men. Urology, 61, 987-992. https://doi.org/10.1016/S0090-4295(02)02588-8

[31] Niang, L., Ndoye, M., Ouattara, A., et al. (2013) Management of Prostate Cancer in 
Senegal; What Is Being Done? Progrès en Urologie, 23, 36-41.

https://doi.org/10.1016/j.purol.2012.09.002

[32] Punga-Maole, A.M., Moningo, D.M., Kayembe, P.K., Tshikuela, M.L. and Kabongo, J.M. (2008) Study of Prostate Cancer Screening in a Population of Employees of a Kinshasa Company in the Democratic Republic of Congo. Detection Rate and $\mathrm{Nu}-$ tritional and Geographical Risk Factors. Progrès en Urologie, 18, 512-518. https://doi.org/10.1016/j.purol.2008.04.009

[33] Zhao, H., Coram, M.A., Nolley, R., Reese, S.W., Young, S.R. and Peehl, D.M. (2012) Transcript Levels of Androgen Receptor Variant AR-V1 or AR-V7 Do Not Predict Recurrence in Patients with Prostate Cancer at Indeterminate Risk for Progression. Journal of Urology, 188, 2158-2164. https://doi.org/10.1016/j.juro.2012.08.014

[34] Smith, M.R., Cook, R., Lee, K.A. and Nelson, J.B. (2011) Disease and Host Characteristics as Predictors of Time to First Bone Metastasis and Death in Men with Progressive Castration-Resistant Non Metastatic Prostate Cancer. Cancer, 117, 2077-2085. https://doi.org/10.1002/cncr.25762

[35] Parker, C., Nilsson, S., Heinrich, D., Helle, S.I., O’Sullivan, J.M., Fossa, S.D., Chodacki, A., Wiechno, P., Logue, J., Seke, M., et al. (2013) Alpha Emitter Radium-223 and Survival in Metastatic Prostate Cancer. The New England Journal of Medicine, 369, 213-223. https://doi.org/10.1056/NEJMoa1213755

[36] Bubendorf, L., et al. (2000) Metastatic Patterns of Prostate Cancer: An Autopsy Study of 1589 Patients. Human Pathology, 31, 578-583.

https://doi.org/10.1053/hp.2000.6698

[37] He, M., Liu, H.N., Cao, J.Y., Wang, Q., Xu, H.T. and Wang, Y.F. (2017) Predicting Castration-Resistant Prostate Cancer after Combined Androgen Blockade. Oncotarget, 8, 105458-105462. https://doi.org/10.18632/oncotarget.22246

[38] Gillessen, S., Omlin, A., Attard, G., de Bono, J.S., Efstathiou, E., Fizazi, K., Halabi, S., Nelson, P.S., Sartor, O., Smith, M.R., Soule, H.R., Akaza, H., Beer, T.M., Beltran, H., Chinnaiyan, A.M., Daugaard, G., Davis, I.D., De Santis, M., Drake, C.G., Eeles, R.A., Fanti, S., Gleave, M.E., Heidenreich, A., Hussain, M., James, N.D., Lecouvet, F.E., Logothetis, C.J., Mastris, K., Nilsson, S., Oh, W.K., Olmos, D., Padhani, A.R., Parker, C., Rubin, M.A., Schalken, J.A., Scher, H.I., Sella, A., Shore, N.D., Small, E.J., Sternberg, C.N., Suzuki, H., Sweeney, C.J., Tannock, I.F. and Tombal, B. (2015) Management of Patients with Advanced Prostate Cancer: Recommandations of the St Gallen Advanced Prostate Cancer Consensus Conference (APCCC) 2015. Annals of Oncology, 26, 1589-1604. https://doi.org/10.1093/annonc/mdv257

[39] Szmulewitz, R.Z., Peer, C.J., Ibraheem, A., Martinez, E., Kozloff, M.F., Carthon, B., Harvey, R.D., Fishkin, P., Yong, W.P., Chiong, E., Nabhan, C., Karrison, T., Figg, W.D., Stadler, W.M. and Ratain, M.J. (2018) Prospective International Randomized Phase II Study of Low-Dose Abiraterone with Food versus Standard Dose Abiraterone in Castration-Resistant Prostate Cancer. Journal of Clinical Oncology, 36, 1389-1395. https://doi.org/10.1200/JCO.2017.76.4381

[40] Ryan, C.J., Molina, A., Li, J., et al. (2013) Serum Androgens as Prognostic Biomarkers in Castration-Resistant Prostate Cancer: Results from an Analysis of a Randomized Phase III Trial. Journal of Clinical Oncology, 31, 2791-2798. https://doi.org/10.1200/JCO.2012.45.4595

[41] Pilon, D., Queener, M., Lefebvre, P., et al. (2016) Cost per Median Overall Survival Month Associated with Abiraterone Acetate and Enzalutamide for Treatment of Patients with Metastatic Castration-Resistant Prostate Cancer. Journal of Medical Economics, 19, 777-784. https://doi.org/10.3111/13696998.2016.1173042

[42] Schweizer, M.T., Huang, P., Kattan, M.W., et al. (2013) Adjuvant Leuprolide with or 
without Docetaxel in Patients with High-Risk Prostate Cancer after Radical Prostatectomy (TAX-3501): Important Lessons for Future Trials. Cancer, 119, 3610-3618. https://doi.org/10.1002/cncr.28270

[43] Ost, P., Bossi, A., Decaestecker, K., De Meerleer, G., Giannarini, G., Karnes, R.J., Roach, M. and Briganti, A. (2015) Metastasis-Directed Therapy of Regional and Distant Recurrences after Curative Treatment of Prostate Cancer: A Systematic Review of the Literature. European Urology, 67, 852-863.

https://doi.org/10.1016/j.eururo.2014.09.004

[44] Miyahira, A.K., Lang, J.M., Den, R.B., Garraway, I.P., Lotan, T.L., Ross, A.E., Stoyanova, T., Cho, S.Y., Simons, J.W., Pienta, K.J. and Soule, H.R. (2016) Multidisciplinary Intervention of Early, Lethal Metastatic Prostate Cancer: Report from the 2015 Coffey-Holden Prostate Cancer Academy Meeting. Prostate, 76, 125-139. https://doi.org/10.1002/pros.23107

[45] Alemayehu, B., Buysman, E., Parry, D., Becker, L. and Nathan, F. (2010) Economic Burden and Health Care Utilization Associated with Castration-Resistant Prostate Cancer in a Commercial and Medicare Advantage US Patient Population. Journal of Medical Economics, 13, 351-361. https://doi.org/10.3111/13696998.2010.491435

[46] Morgan, C., McEwan, P., Chamberlain, G., Cabrera, C. and Parry, D. (2010) Castration-Resistant Prostate Cancer (CRPC): A UK Epidemiology Study. Value Health, 13, A26. https://doi.org/10.1016/S1098-3015(10)72108-2

[47] Berruti, A., Tucci, M., Mosca, A., Tarabuzzi, R., et al. (2005) Predictions Factors for Skeletal Complications in Hormone-Refractory Prostate Cancer Patients with $\mathrm{Me}$ tastatic Bone Disease. British Journal of Cancer, 93, 633-638. https://doi.org/10.1038/sj.bjc.6602767

[48] Halabi, S., Dutta, S., Tangen, C.M., Rosenthal, M., Petrylak, D.P., Thompson, I.M., Chi, K.N., Araujo, J.C., Logothetis, C., Quinn, D.I., Fizazi, K., Morris, M.J., Eisenberger, M.A., George, D.J., De Bono, J.S., Higano, C.S., Tannock, I.F., Small, E.J. and Kelly, W.K. (2019) Overall Survival of Black and White Men with Metastatic Castration-Resistant Prostate Cancer Treated with Docetaxel. Journal of Clinical Oncology, 37, 403-410. https://doi.org/10.1200/JCO.18.01279

[49] Bianco, F.J., Wood, D.P., Cher, M.L., Powell, I.J., et al. (2003) Ten-Year Survival after Radical Prostatectomy: Specimen Gleason Score Is the Predictor in Organ-Confined Prostate Cancer. Clinical Prostate Cancer, 1, 242-247. https://doi.org/10.3816/CGC.2003.n.006

[50] Cheville, J.C., Tindall, D., Boelter, C., et al. (2002) Metastatic Prostate Carcinoma, Clinical and Pathologic Features Associated with Cancer-Specific Survival. Cancer, 95, 1028-1036. https://doi.org/10.1002/cncr.10788

[51] Sundi, D., Wang, V.M., Pierorazio, P.M., Han, M., Bivalacqua, T.J., Ball, M.W., Antonarakis, E.S., Partin, A.W., Schaeffer, E.M. and Ross, A.E. (2014) Very-High-Risk Localized Prostate Cancer: Definition and Outcomes. Prostate Cancer and Prostatic Diseases, 17, 57-63. https://doi.org/10.1038/pcan.2013.46

[52] Chin, S.N., Wang, L., Moore, M. and Sridhar, S.S. (2010) A Review of the Patterns of Docetaxel Use for Hormone-Resistant Prostate Cancer at the Princess Margaret Hospital. Current Oncology, 17, 24-29. https://doi.org/10.3747/co.v17i2.482

[53] Schröder, F.H. and Roobol, M.J. (2010) ERSPS and PLCO Prostate Cancer Screening Studies: What Are the Differences? European Urology, 58, 46-52. https://doi.org/10.1016/j.eururo.2010.03.033

[54] Salomon, L., Azria, D., Bastide, C., Beuzeboc, P., Cormier, L., Cornu, F., et al. (2010) Comité de Cancérologie de l'AFU. Recommandations en onco-urologie: Cancer de 
la prostate. Progrès en Urologie, 20, S21.

https://doi.org/10.1016/S1166-7087(10)70042-7

[55] Bolla, M., Maingon, P., Carrie, C., et al. (2016) Short Androgen Suppression and Radiation Dose Escalation for Intermediate- and High-Risk Localized Prostate Cancer: Results of EORTC Trial 22991. Journal of Clinical Oncology, 34, 1748-1756. https://doi.org/10.1200/JCO.2015.64.8055

[56] D’Amico, A.V., Chen, M.H., Renshaw, A., et al. (2015) Long-Term Follow-Up of a Randomized Trial of Radiation with or without Androgen Deprivation Therapy for Localized Prostate Cancer. JAMA, 314, 1291-1293.

https://doi.org/10.1001/jama.2015.8577

[57] Choquenet, C., et al. (1997) Survie des cancers de prostate avec métastases: 71 malades suivis de 7 à 11 ans. Progrès en Urologie, 7, 254-258.

[58] Soerdjbalie-Maikoe, V., Pelger, R.C., Lycklama a Nijeholt, G.A., Arndt, J.W., et al. (2004) Bone Scintigraphy Predicts the Risk of Spinal Cord Compression in Hormone Refractory Prostate Cancer. European Journal of Nuclear Medicine and Molecular Imaging, 31, 958-963. https://doi.org/10.1007/s00259-004-1479-Z

[59] Inoue, T., Segawa, T., Kamba, T., Yoshimura, K., et al. (2009) Prevalence of Skeletal Complications and Their Impact on Survival of Hormone Refractory Prostate Cancer Patients in Japan. Urology, 73, 1104-1109.

https://doi.org/10.1016/j.urology.2008.07.062

[60] Smaletz, O., Scher, H.I., Small, E.J., et al. (2002) Nomogram for Overal Survival of Patients with Progressive Metastatic Prostate Cancer after Castration. Journal of Clinical Oncology, 20, 3972-3982. https://doi.org/10.1200/JCO.2002.11.021

[61] Armstrong, A.J., Garrett-Mayer, E., de Wit, R., Tannock, I. and Eisenberger, M. (2010) Prediction of Survival Following First-Line Chemotherapy in Men with Castration-Resistant Metastatic Prostate Cancer. Clinical Cancer Research, 16, 203-211. https://doi.org/10.1158/1078-0432.CCR-09-2514

[62] Metwalli, A.R., Rosner, I.L., Cullen, J., Chen, Y., Brand, T., Brassell, S.A., Lesperance, J., Porter, C., Sterbis, J. and Mc Leod, D.G. (2014) Elevated Alkaline Phosphatase Velocity Strongly Predicts Overall Survival and the Risk of Bone Metastases in Castrate-Resistant Prostate Cancer. Urologic Oncology, 32, 761.

https://doi.org/10.1016/j.urolonc.2014.03.024

[63] Moreira, D.M., Howard, L.E., Sourbeer, K.N., Amarasekara, H.S., Chow, L.C., Cockrell, D.C., Hanyok, B.T., Pratson, C.L., Aronson, W.J., Kane, C.J., et al. (2015) Predicting Bone Scan Positivity in Non-Metastatic Castration-Resistant Prostate Cancer. Prostate Cancer and Prostatic Diseases, 18, 333-337. https://doi.org/10.1038/pcan.2015.25 


\section{Appendix}

DATA COLLECTION SHEETS

Subject: "EVOLUTION OF ANDROGENIC DEPRIVATION IN TREATMENT OF PROSTATE CANCER IN KINSHASA"

Date of collection at the Pointe à Pitre/Matete Clinic

March 2014 to June 2018.

I. IDENTITY

Coded

Place and date of birth

Weight (kg)

$\mathrm{kg}$

Height (cm)

$\mathrm{cm}$

Marital status

Married:

Divorced:

Single:

Widower:

Age (year)

............... years

Address

C:

Q:

Av:

Profession

Province of origin

Phone number

II. MEDICAL HISTORY

1) Personal

- Smoker

- Former smoker

- How many stems/day

- Allergy to a drug

- (which)?

- Hypertensive

Yes $\square \quad$ No $\square$

Yes $\square \quad$ No $\square$

Yes $\square \quad$ No $\square$

Yes $\square \quad$ No $\square$

- Diabetic

Yes No

- Fracture, in the absence of major trauma

(If yes, which fracture site)

- Hyperuricemia

Yes $\square \quad$ No $\square$

- Alcohol

Yes $\square \quad$ No $\square$

2) Family history

- Prostate cancer

Yes $\square \quad$ No $\square$

- Breast cancer

Yes $\square \quad$ No $\square$

\section{CLINICAL FINDING}

Dominant symptom

Functional signs: 1. pain:

$$
\begin{aligned}
& \text { - Pain in RT } \\
& \text { - Bone pain }
\end{aligned}
$$

$\begin{array}{ll}\text { Yes } \square & \text { No } \square \\ \text { Yes } \square & \text { No } \square\end{array}$


2) Urinary disorder:

$\begin{array}{lcc}\text { - dysuria } & \text { Yes } \square & \text { No } \square \\ \text { - incontinence } & \text { Yes } \square & \text { No } \square \\ \text { - mictalgia } & \text { Yes } \square & \text { No } \square \\ \text { - pollakiuria } & \text { Yes } \square & \text { No } \square \\ \text { - nocturia } & \text { Yes } \square & \text { No } \square \\ \text { - resumes post-voiding } & \text { Yes } \square & \text { No } \square\end{array}$

3) Rectal touch:

$\begin{array}{lcc}\text { - nodule } & \text { Yes } \square & \text { No } \square \\ \text { - invasion } & \text { Yes } \square & \text { No } \square \\ \text { - lumbar contact } & \text { Yes } \square & \text { No } \square \\ \text { - Lower limb edema } & \text { Yes } \square & \text { No } \square\end{array}$

\section{PARACLINIC}

Imaging:

$\begin{array}{lcc}\text { - endorectal ultrasound } & \text { Yes } \square & \text { No } \square \\ \text { - MRI } & \text { Yes } \square & \text { No } \square \\ \text { - Abdomino-pelvic scanner } & \text { Yes } \square & \text { No } \square \\ \text { - bone scan } & \text { Yes } \square & \text { No } \square\end{array}$

Prostate biopsy:

- Performed

Yes $\square \quad$ No $\square$

- Positive result

Yes $\square \quad$ No $\square$

Method of realization:

$\begin{array}{lll}\text { - echoguided } & \text { Yes } \square & \text { No } \square \\ \text { - transrectal } & \text { Yes } \square & \text { No } \square\end{array}$

Initial stage

$\begin{array}{lll}\text { - localized cancer } & \text { Yes } \square & \text { No } \square \\ \text { - locoregional cancer } & \text { Yes } \square & \text { No } \square \\ \text { - metastatic cancer } & \text { Yes } \square & \text { No } \square\end{array}$

Clinical classification/Imaging, cTNM cT....................

Gleason score

Testosteroneemia $(\mathrm{ng} / \mathrm{ml})$

$(1 \ldots \ldots),.(2 \ldots \ldots .),.(3 \ldots \ldots .),.(4 \ldots \ldots)$

PSA $(\mathrm{ng} / \mathrm{ml})$

$(1 \ldots \ldots),.(2 \ldots \ldots .),.(3 \ldots \ldots .),.(4 \ldots \ldots$.

D’AMICO classe: Low risk (1), Intermediate risk, (2) High risk (3), Metastatic (4)

\section{TREATMENT}

1) Hormone therapy used

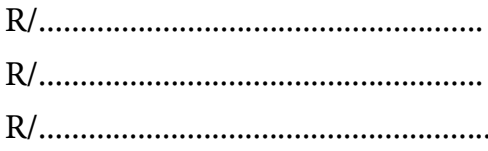

Start of treatment (month/year)

Duration

2) Anti-androgen therapy?

Yes $\square \quad$ No $\square$

Which?

$\mathrm{R} /$.

$\mathrm{R} /$. 
3) Surgical castrations

Others

Complications:

$$
\begin{aligned}
& \text { - Early } \\
& \text {-late }
\end{aligned}
$$

Evolution of castration

Evolutions of testosterone

Time to onset of castration resistance after treatment is indicated

Death

Death with cancer

Other causes

$\mathrm{R} /$.

$\mathrm{R} / \ldots$
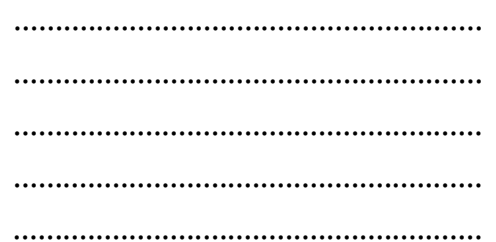

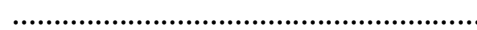

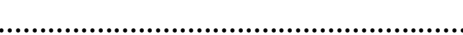

Yes $\square \quad$ No $\square$

Yes $\square \quad$ No $\square$

Age:

Time after treatment.

\section{$\mathrm{R} /$.}

